\title{
Concurrent capecitabine and whole-brain radiotherapy for treatment of brain metastases in breast cancer patients
}

\author{
Cyrus Chargari · Youlia M. Kirova · Véronique Diéras · Pablo Castro Pena \\ Francois Campana - Paul H. Cottu · JeanYves Pierga · Alain Fourquet · \\ Institut Curie Breast Cancer Study Group
}

Published online: 21 March 2009

(C) Springer Science+Business Media, LLC. 2009

Erratum to: J Neurooncol

DOI 10.1007/s11060-008-9791-2

The fourth author's name was misrepresented in the original publication. The correct name is shown in this erratum.

The online version of the original article can be found under doi:10.1007/s11060-008-9791-2.

C. Chargari · Y. M. Kirova ( $₫)$ - V. Diéras · P. Castro Pena · F. Campana · P. H. Cottu - J. Pierga - A. Fourquet

Department of Radiation Oncology, Department of Medical Oncology, Institut Curie, 26, Rue d’Ulm, 75005 Paris, France

e-mail: youlia.kirova@curie.net

Institut Curie Breast Cancer Study Group

Institut Curie, Paris, France 